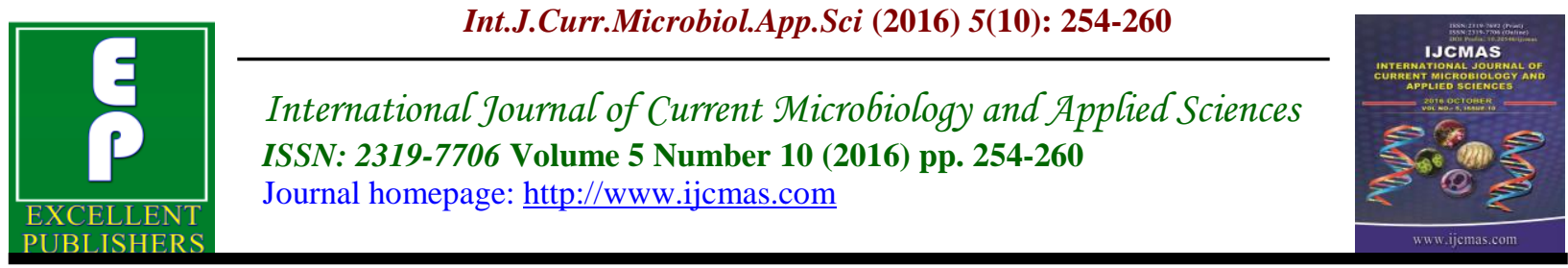

Original Research Article

http://dx.doi.org/10.20546/ijcmas.2016.510.028

\title{
Detection of Aspergillus Species by Polymerase Chain Reaction
}

\author{
Raksha Singh ${ }^{1}$, Gurjeet Singh $^{2} *$ and A.D. Urhekar ${ }^{1}$ \\ ${ }^{1}$ Department of Microbiology, MGM Medical College and Hospital, MGM Institute of Health \\ Sciences, Kamothe, Navi Mumbai-410209, Maharashtra, India \\ ${ }^{2}$ Department of Microbiology, NC Medical College and Hospital, Israna, \\ Panipat-132107, Haryana, India \\ *Corresponding author
}

A B S T R A C T

Keywords

Aspergillus,

Polymerase

Chain Reaction,

Sensitivity,

Patient

\section{Article Info}

Accepted:

14 September 2016

Available Online:

10 October 2016
Aspergillus species have recently caused increasing numbers of acute invasive infections in immunocompromised patients. This prospective and experimental study was carried out at Department of Microbiology and Central Research Laboratory, MGM Medical College and Hospital, Navi Mumbai. Detection of Aspergillus species was done using Polymerase Chain Reaction. This detection level (sensitivity 25\%) is higher than Culture (19.5\%), Fluorescence (17\%) and Microscopy (10\%) and difference in sensitivity is statically significant $\mathrm{P}$ value (0.001) $<0.05$, Significant. Species detection in nested PCR was A. niger (50\%), A.fumigatus (35\%) and A.flavus (15\%). This shows more species specificity of PCR. Molecular methods are more sensitive and specific methods. It gives results for detection and speciation in short time which helps early diagnosis and treatment of patient.

\section{Introduction}

Aspergillus species have recently caused increasing numbers of life-threatening acute invasive infections in immunocompromised patients (Kontoyiannis et al., 2002). The steadily increasing incidence of invasive aspergillosis over the last few decades is ascribable to the increasing number of patients undergoing chemotherapy, bone marrow or solid organ transplantation and intensive corticosteroid therapy (Yamazaki et al., 1999).

Conventional diagnosis of fungal infection relies on the identification of pathogens by means of morphological characters specific to the genus and species. This is sometimes unsuccessful, however, because of the atypical features of some isolates. Molecular biological identification systems for pathogenic aspergilli have been suggested as a solution to this problem: for example, a PCR based diagnostic method for detecting the genus Aspergillus using 18S rDNA (Makimura et al., 1994; Yamakami et al., 1996; Gaskell et al., 1997) has been designed. Systems have also been described for specific detection of Aspergillus fumigatus with primers based on regions of the 28S rDNA or of the internal transcribed spacer (ITS) 1 and 2 regions of ribosomal DNA (rDNA) (Radford, 1998; Henry et al., 2000). These PCR systems described to date 
are useful only in identifying the genus Aspergillus as a whole or the single species A. fumigatus. The ITS region contains variable elements that allow for sequencebased identification of Aspergillus species (Iwen et al., 2002); therefore, the region offers a possible template for design of species-specific primers for identification of the major pathogenic species.

Because the number of species of pathogenic fungi known to infect immunocompromised patients is growing, (Sugita et al., 2004) it is essential that quick and reliable methods of identification be found for the most common pathogenic species of aspergilli. This means that not just A. fumigatus, but also Aspergillus flavus and $A$. niger, should be rapidly identified by a successful system.

\section{Materials and Methods}

This prospective and analytical study was conducted at Microbiology laboratory and Central Research laboratory, MGM Medical College and Hospital, Navi Mumbai, Maharashtra, India. Total 200 sputum samples were collected from Aspergillosis suspected patients. $\mathrm{KOH}$ mount and examined by light microscopy and all samples were also subjected to Calcofluor white stained examined by Fluorescence microscope test and PCR.

\section{Sample collection}

3-5 $\mathrm{ml}$ of sputum was collected from patient attending a tertiary care hospital in a sterile container taking all sterile precaution and properly labeled the container with patient's name, date and time.

\section{Primer sequences}

The oligonucleotide primers used in this study are as described in the table 1. The primers were obtained from Sigma, USA.

\section{PCR specification}

PCR amplifications were performed in accordance to a procedure as followed by Sugita et al., (2004) According to the procedure master mix "BioMix Red"

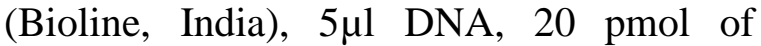
primers were added and mixed to obtain $50 \mu 1$ final volume of the PCR mix.

\section{Results and Discussion}

PCR-based detection or identification systems for Aspergillus species were based on using $18 \mathrm{~S}$ or $28 \mathrm{~S}$ rDNA as target DNA. However, the sequences in these regions are conserved across a wide range of fungi; it is therefore difficult to design truly speciesspecific primers. As reported previously, the more variable ITS regions have proven more useful for identification of fungal species (Henry et al., 2000).

The present study using specific PCR amplification to allow identification not just of $A$. niger but also A. fumigatus and $A$. flavus, the second and third most frequently significant Aspergillus species in opportunistic infection, using specific PCR amplification. The importance of these species should not be underestimated. The number of infections they cause is increasing (Hoshino et al., 1999; Nenoff et al., 2002).

Nested PCR for Aspergillus species (Niger, fumigates, flavus) was performed by using species specific primer sets Nig, Fmi and Fla. The method followed by as per Sugita C et al., (2004). Out of 200 PCR test runs on sputum samples, with 50 samples showed presence of Aspergillus genome. This detection level (sensitivity 25\%) is higher than Culture (19.5\%), Fluorescence (17\%) and Microscopy (10\%) and difference in sensitivity is statically significant. Microscopy Vs. PCR , P value ( 0.001) $<0.05$, Significant. 
Table.1 Primers for nested PCR of 18S rRNA gene in Aspergillus species.10

\begin{tabular}{|c|c|c|c|c|}
\hline $\begin{array}{l}\text { Name } \\
\text { organism }\end{array}$ & $\begin{array}{l}\text { Primer } \\
\text { set }\end{array}$ & Primers & Oligonuleotides & $\begin{array}{l}\text { Gene } \\
\text { accession } \\
\text { No. }\end{array}$ \\
\hline \multirow{2}{*}{$\begin{array}{l}\text { Aspergillus } \\
\text { species }\end{array}$} & \multirow{2}{*}{ ASAP } & ASAP1 & 5'-CAGCGAGTACATCACCTTGG-3' & KP987074.1 \\
\hline & & ASAP2 & 5'-CCATTGTTGAAAGTTTTAACTGATT-3' & KP657690.1 \\
\hline \multirow[t]{2}{*}{ A. fumigatus } & \multirow[t]{2}{*}{ Fmi } & ASPU & 5'-ACTACCGATTGAATGGCTCG-3' & KR023997.1 \\
\hline & & Af3r & 5'-CATACTTTCAGAACAGCGTTCA-3' & LC133095.1 \\
\hline \multirow[t]{2}{*}{ A. niger } & \multirow[t]{2}{*}{ Nig } & ASPU & 5'-ACTACCGATTGAATGGCTCG-3' & KF304798.1 \\
\hline & & Nilr & 5'-ACGCTTTCAGACAGTGTTCG-3' & LC133092.1 \\
\hline \multirow[t]{2}{*}{ A. flavus } & \multirow[t]{2}{*}{ Fla } & ASPU & 5'-ACTACCGATTGAATGGCTCG-3' & KP784374.1 \\
\hline & & Fl2r & 5'-TTCACTAGATCAGACAGAGT-3' & LC133097.1 \\
\hline \multirow{2}{*}{$\begin{array}{l}\text { Pan-fungal } \\
\text { primers }\end{array}$} & \multirow{2}{*}{$\begin{array}{l}18 \mathrm{~S} \\
\text { rDNA }\end{array}$} & B2F & 5'-ACTT & KT935264.1 \\
\hline & & B4R & 5'-TGATCGTCTTCGATCCCCTA-3' & KT935264.1 \\
\hline
\end{tabular}

Table.2 Cycling conditions of first- and nested-step PCR reactions.10

\begin{tabular}{|l|l|}
\hline Reaction $^{\text {a }}$ & Cycling conditions \\
\hline $\begin{array}{l}\text { First step (Aspergillus } \\
\text { species) }\end{array}$ & $\begin{array}{l}\text { Initial Denaturation at } 94^{\circ} \mathrm{C} \text { for } 4 \text { min, Denaturation at } 94^{\circ} \mathrm{C} \text { for } \\
1 \mathrm{~min} \text {, annealing at } 55^{\circ} \mathrm{C} \text { for } 2 \mathrm{~min} \text {, and extension at } 72^{\circ} \mathrm{C} \text { for } \\
90 \mathrm{Sec}(30 \text { cycles). Thermal cycling was terminated by } \\
\text { polymerization at } 72^{\circ} \mathrm{C} \text { for } 10 \mathrm{~min} .\end{array}$ \\
\hline $\begin{array}{l}\text { For the species specific } \\
\text { primer sets Fmi, Nig, and } \\
\text { Fla. }\end{array}$ & $\begin{array}{l}\text { Initial Denaturation at } 94^{\circ} \mathrm{C} \text { for } 4 \mathrm{~min} \text {, Denaturation at } 94^{\circ} \mathrm{C} \text { for } \\
1 \mathrm{~min} \text { annealing at } 60^{\circ} \mathrm{C} \text { for } 15 \mathrm{Sec} \text {, and extension at } 72^{\circ} \mathrm{C} \text { for } \\
15 \text { Sec }(25 \text { cycles). Thermal cycling was terminated by } \\
\text { polymerization at } 72^{\circ} \mathrm{C} \text { for } 10 \text { min. }\end{array}$ \\
\hline
\end{tabular}

Table.3 Showing different methods for detection of Aspergillus species.

\begin{tabular}{|l|c|c|c|}
\hline Methods & Positive & Negative & Percentages \\
\hline Microscopy (n=200) & 20 & 180 & $10 \%$ \\
\hline Fluorescence microscopy (n=200) & 34 & 166 & $17 \%$ \\
\hline Culture (n=200) & 39 & 161 & $19.5 \%$ \\
\hline PCR (n=80) & 20 & 60 & $25 \%$ \\
\hline
\end{tabular}


Table.4 Showing Aspergillus speciation by PCR method.

\begin{tabular}{|l|l|l|}
\hline Aspergillus species & Positive No. & Percentages \\
\hline A. niger & 10 & $50 \%$ \\
\hline A. fumigatus & 7 & $35 \%$ \\
\hline A. flavus & 3 & $15 \%$ \\
\hline Total & 20 & $100 \%$ \\
\hline
\end{tabular}

Fig.1 Showing confirmation of Aspergillus species.

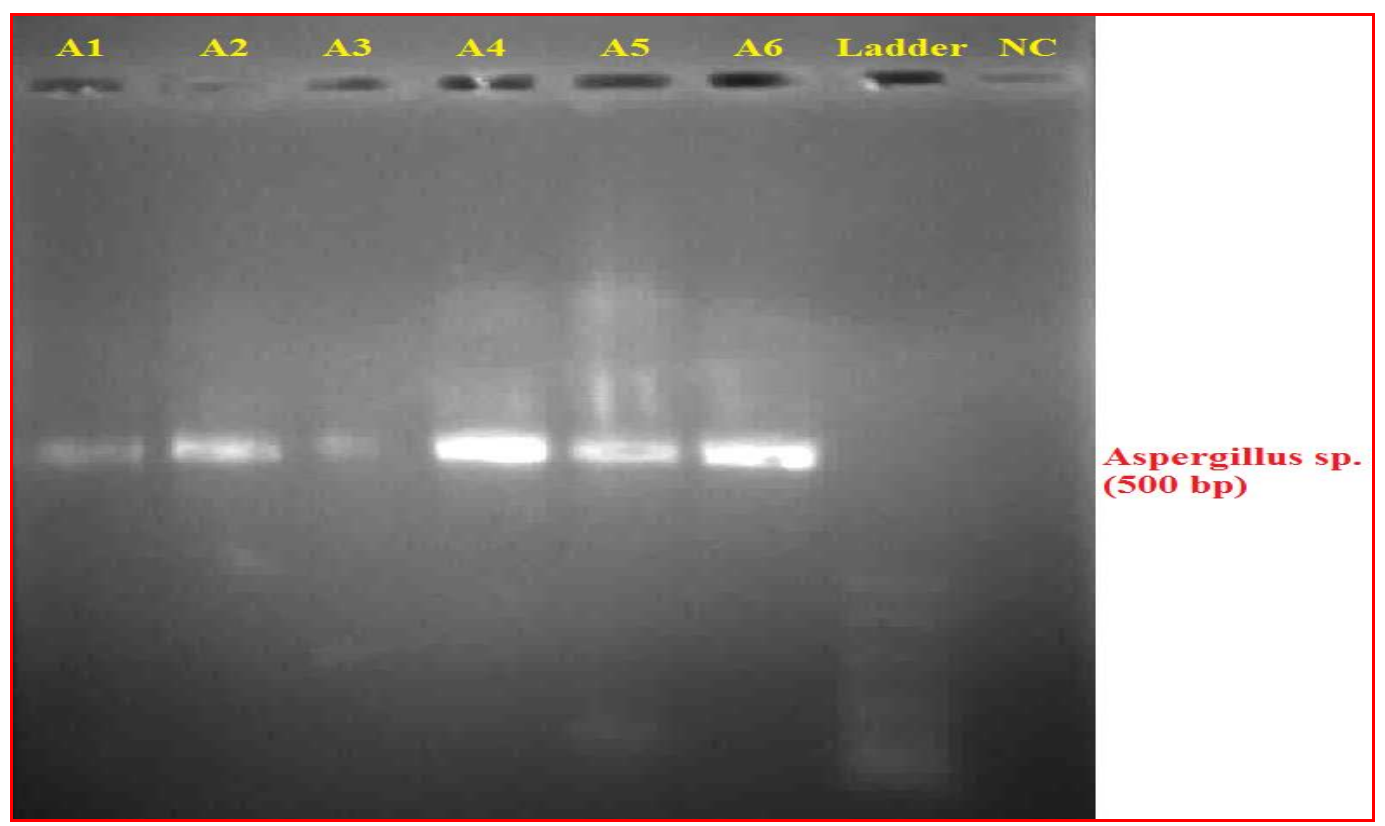

Fig.2 Showing species characterization of Aspergillus species (A1 $\rightarrow$ A. flavus, A2-A $5 \rightarrow$ A. niger, A-6-A7 $\rightarrow$ A. fumigatus).

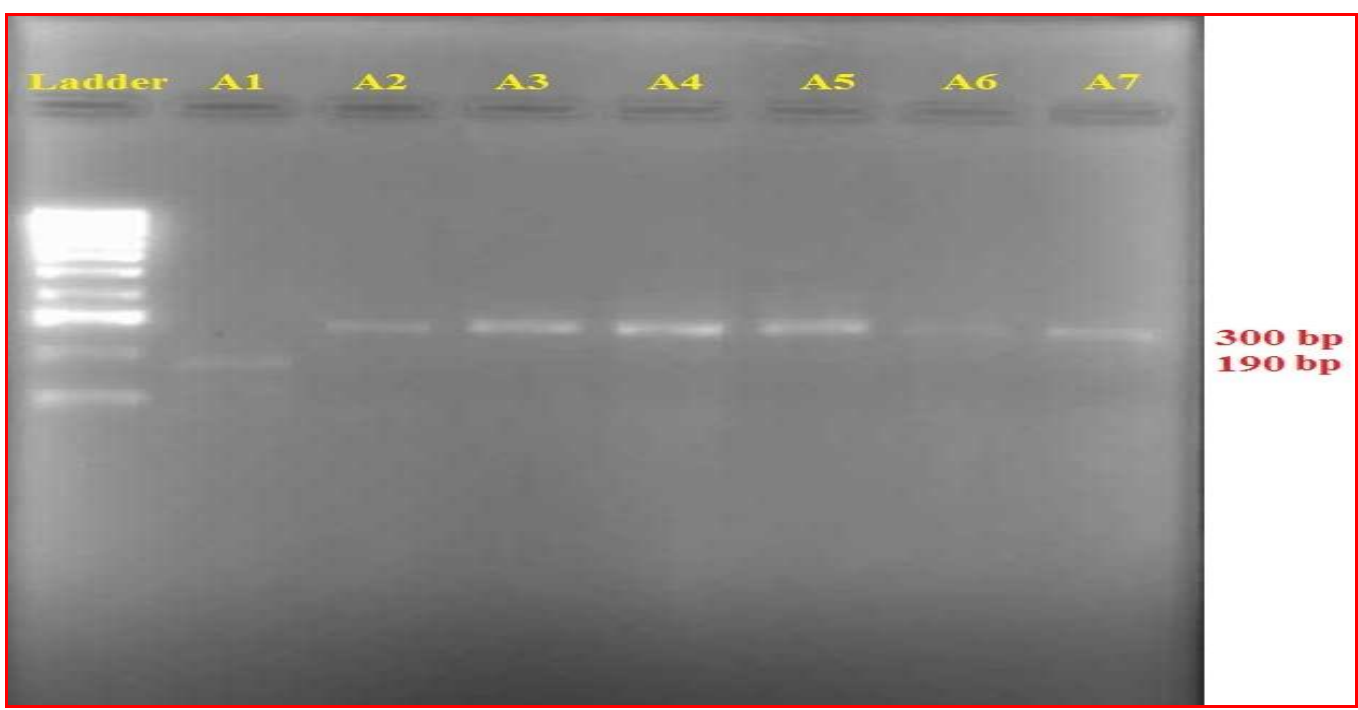


Fig.3 Showing Aspergillus species detection by various methods.

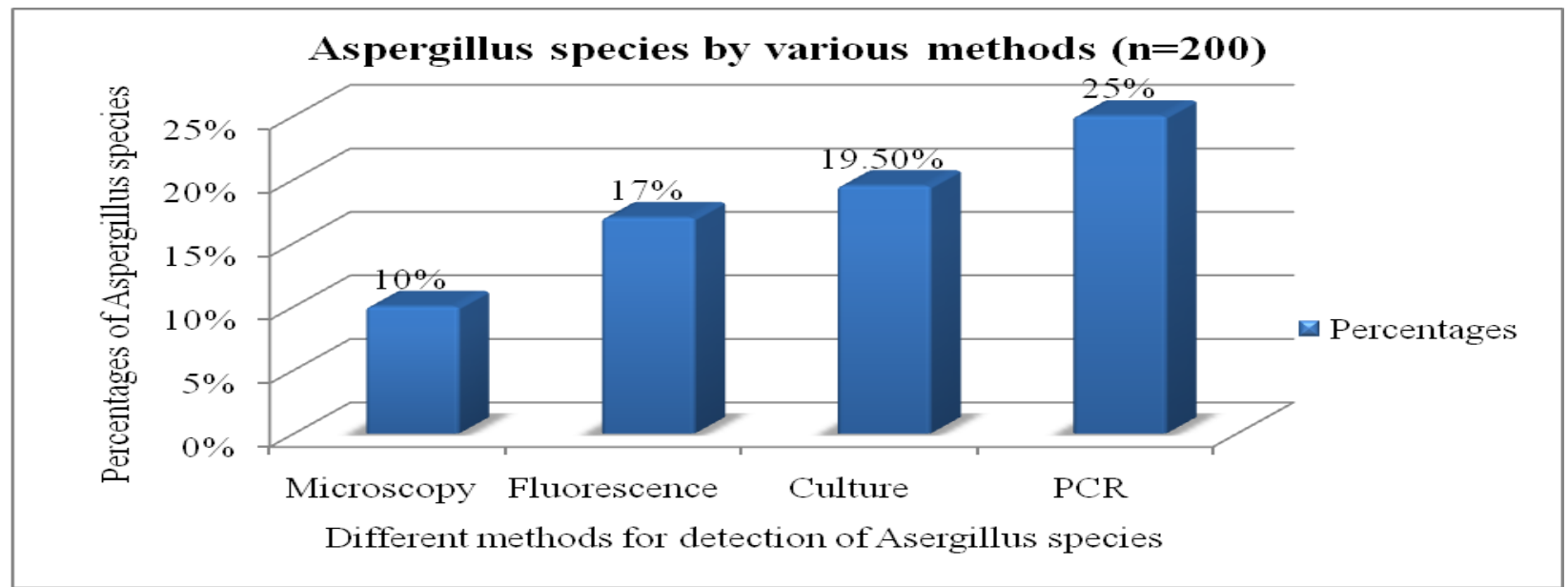

Fig.4 Showing Aspergillus speciation by PCR methods.

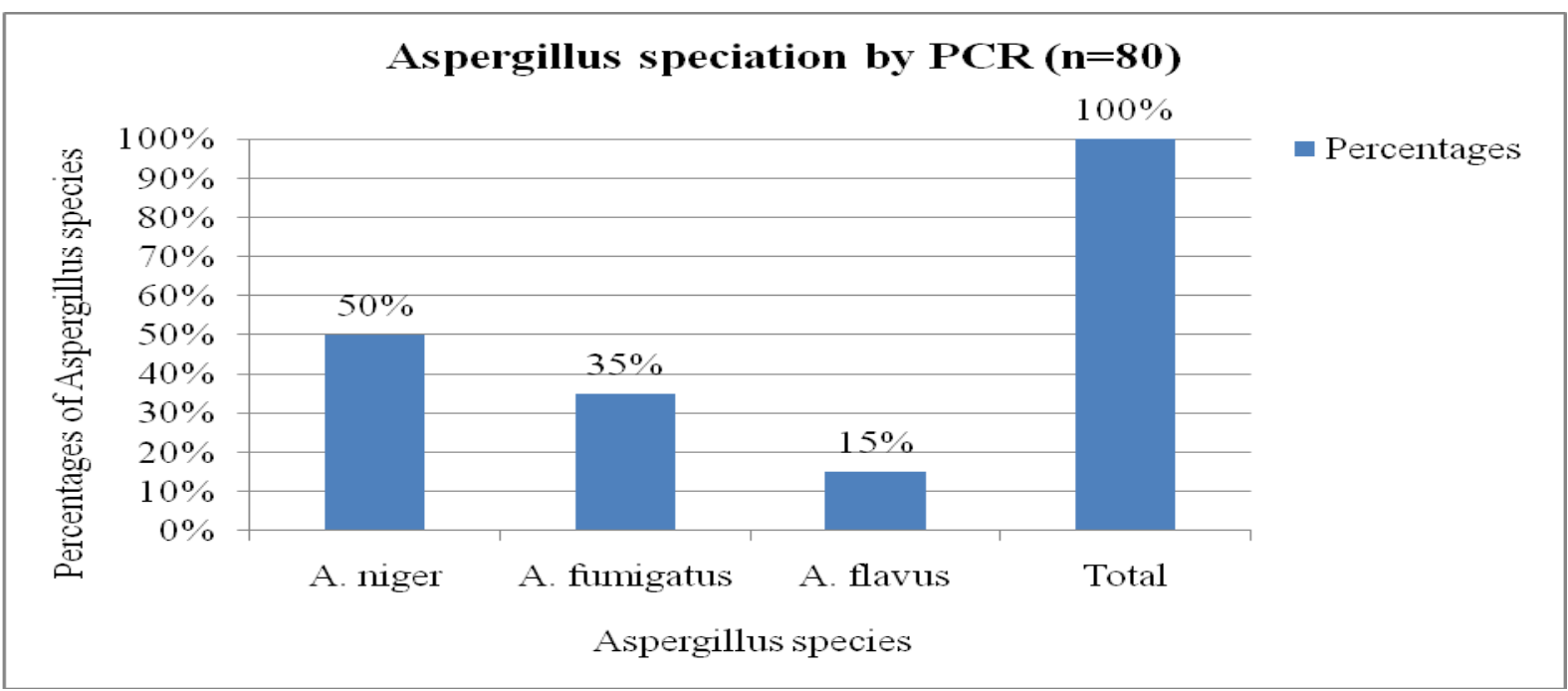

Species detection in nested PCR was $A$. niger (50\%), A.fumigatus (35\%) and A.flavus (15\%). This shows more species specificity of PCR.

Most of the PCR studies for aspergillosis were done in other countries-Christop et al., [1993 from United Kingdom], Hayette et al., (2001 from Belgium), Loeffler et al., (2002 Germany), Sugita et al., (2004 from Japan), White et al., (2006 United Kingdom), Diba et al., (2014 from Iran).

Studies from India -
a) Bagyalakshmi et al., (2007 from Chennai) studied on 168 ocular

specimen. Smear examination (20.23\%), Culture (25\%), PCR(53.57\%).

b) Deshpande et al., (2011 from Maharashtra) studied on 71 cases . Out of which PCR positive (18.30\%).

All the above mentioned studies showed high level of sensitivity and specificity of PCR for detection of Aspergillus.

In conclusion, nested PCR for Aspergillus species (niger, fumigatus, flavus) on sputum samples which showed presence of infection (pus cells) was performed by using species specific primer sets Nig, Fmi and Fla. 
Comparison of nested PCR with other methods showed high sensitivity and specificity (Microscopy 10\%, Fluorescence microscopy $17 \%$, Culture $19.5 \%$ and PCR $25 \%)$.

Molecular methods are more sensitive and specific methods. It gives results for detection and speciation in short time which helps early diagnosis and treatment of patient.

\section{References}

Bagyalakshmi, R., Therese, K.L., Madhavan, H.N. 2007. Application of semi-nested polymerase chain reaction targeting internal transcribed spacer region for rapid detection of panfungal genome directly from ocular specimens. Indian J. Ophthalmol., 55: 261-5.

Christoph, M., Tang, David, W., Holden, Agnès Aufauvre-Brown, Jonathan Cohen. 1993. "The Detection of Aspergillus spp. by the Polymerase Chain Reaction and Its Evaluation in Bronchoalveolar Lavage Fluid", American Rev. Respiratory Dis., 148(5): 1313-1317. doi: 10.1164/ajrccm/148.5.1313

Deshpande, P., Hedge, A., Kapadia, F., Mehta, A., Rodrigues, C., Shetty, A., Soman, R. 2011. Standardization of fungal polymerase chain reaction for the early diagnosis of invasive fungal infection. Indian J. Med. Microbiol., 29(4): 406-410.

Diba, K., Mirhendi, H., Kordbacheh, P., Rezaie, S. 2014. Development of RFLP-PCR method for the identification of medically important Aspergillus species using single restriction enzyme MwoI. Brazilian J. Microbiol., 45(2): 503-507.
Gaskell, G.J., Carter, D.A., Britton, W.J., Tovey, E.R., Benyon, F.H., Lovborg, U. 1997. Analysis of the internal transcribed spacer regions of ribosomal DNA in common airborne allergenic fungi. Electrophoresis, 18: 1567-1569.

Hayette, M., Vaira, D., Susin, F., Boland, P., Christiaens, G., Melin, P., Mol, P.D. Detection of Aspergillus Species DNA by PCR in Bronchoalveolar Lavage Fluid. J. Clin. Microbiol., 39(6): 2338-2340.

Henry, T., Iwen, P.C., Hinrichs, S.H. 2000. Identification of Aspergillus species using internal transcribed spacer regions 1 and 2. J. Clin. Microbiol., 38: 1510-1515.

Henry, T., Iwen, P.C., Hinrichs, S.H. 2000. Identification of Aspergillus species using internal transcribed spacer regions 1 and 2. J. Clin. Microbiol., 38: 1510-1515.

Hoshino, H., Tagaki, S., Kon, H. et al. 1999. Allergic bronchopulmonary aspergillosis due to Aspergillus niger without bronchial asthma. Respiration, 66: 369-372.

Iwen, P.C., Hinrichs, S.H., Rupp, M.E. 2002. Utilization of the internal transcribed spacer regions as molecular targets to detect and identify human fungal pathogens. Med. Mycol., 40: 87-109.

Kontoyiannis, D.P., Bodey, G.P. 2002. Invasive aspergillosis in: an update. Eur. J. Clin. Microbiol. Infect. Dis., 21: 161-172.

Loeffler, J., Kloepfer, K., Hebart, H., Najvar, L., Graybill, J.R., Kirkpatrick, W.R., Patterson, T.F., Dietz, K., Bialek, R., Einsele, H. 2002. Polymerase Chain Reaction Detection of Aspergillus DNA in Experimental Models of Invasive Aspergillosis. J. Infect. Dis., 185: 1203-6. 
Makimura, K., Murayama, S.Y., Yamaguchi, H. 1994. Specific detection of Aspergillus and Penicillium species from respiratory specimens by polymerase chain reaction (PCR). Jpn. J. Med. Sci. Biol., 47: 141-156.

Nenoff, P., Kliem, C., Mittag, M., Horn, L.C., Niederwieser, D., Haustein, U.F. 2002. Secondary cutaneous aspergillosis due to Aspergillus flavus in an acute myeloid leukaemia patient following stem cell transplantation. Eur. J. Dermatol., 12: 93-98.

Radford, S.A., Johnson, E.M., Leeming, J.P., et al. 1998. Molecular epidemiological study of Aspergillus fumigatus in a bone marrow transplantation unit by PCR amplification of ribosomal intergenic spacer sequences. J. Clin. Microbiol., 36: 1294-1299.

Rao, K., Saha, V. 2000. Medical management of Aspergillus flavus endocarditis. Pediatr. Hematol. Oncol., 17: 425-427.

Sugita, C., Makimura, K., Uchida, K., Yamaguchi, H., Nagai, A. 2004. PCR identification system for the genus Aspergillus and three major pathogenic species: Aspergillus fumigatus, Aspergillus flavus and Aspergillus niger. Med. Mycol., 42: 433-437.

White, P.L., Linton, C.J., Perry, M.D., Johnson, E.M., Barnes, R.A. 2006. The Evolution and Evaluation of a Whole Blood Polymerase Chain Reaction Assay for the Detection of Invasive Aspergillosis in Hematology Patients in a Routine Clinical Setting. Clin. Infect. Dis., 42: 479-86.

Yamakami, Y., Hashimoto, A., Tokimatsu, I., Nasu, M. 1996. PCR Detection of DNA specific for Aspergillus species in serum of patients with invasive aspergillosis. J. Clin. Microbiol., 34: 2464-2468.

Yamazaki, T., Kume, H., Murase, S., Yamashita, E., Arisawa, M. 1999. Epidemiology of visceral mycoses: analysis of data in annual of the pathological autopsy cases in Japan. $J$. Clin. Microbiol., 37: 1732-1738.

Zhao, J., Kong, F., Li, R., Wang, X., Wa, Z., Wang, D. 2001. Identification of Aspergillus fumigatus and related species by nested PCR targeting ribosomal DNA internal transcribed spacer regions. J. Clin. Microbiol., 9: 2261-2266.

\section{How to cite this article:}

Raksha Singh, Gurjeet Singh and A.D. Urhekar. 2016. Detection of Aspergillus Species by Polymerase Chain Reaction. Int.J.Curr.Microbiol.App.Sci. 5(10): 254-260. doi: http://dx.doi.org/10.20546/ijcmas.2016.510.027 